\title{
Assessment of Microbiological Parameters of Water and Waste Waters In and Around Vijayawada
}

\author{
V. Jayalakshmi* and N. Lakshmi** \\ **Dean, School of Life Sciences, Head Department of Microbiology, Montessori Mahila Kalasala, Rtd. \\ Professor, Nagarjuna University, Vijayawada-520010, Andhra Pradesh, India. \\ *Department of Microbiology, Montessori Mahila Kalasala, Nagarjuna University, Vijayawada-520010,
}

Andhra Pradesh, India.

\begin{abstract}
The microbiological parameters of water and waste waters in and around Vijayawada were studied in the months of January-December 2012 for a period of one year from seven different sites. Selected sites are Krishna river water (site-I), exit canal near Vijayawada thermal power plant(site-II), canal near agricultural fields(site-III), water present in agricultural fields(site-IV), drain water near SIRIS company(site-V), drain water near railway station(site-VI) and drain water near bus stand(site-VII). Water samples were analyzed for various microbiological parameters using various techniques. Results revealed the existence of actinomycetes, fungi and bacteria in varying frequencies in different seasons. In all the sites, in all seasons except in site-II, the bacterial counts were more than the guide line value of 10/100ml indicating that total plate count and faecal coliform pollution was wide spread. Actinomycetes were predominant in Krishna river water and water present in agricultural fields while their number was negligible in drain waters. The number of fungal colonies in all the sites does not exceed the guide level number in majority of the months. The biochemical identification of the isolate in the Krishna river water sample showed the presence of E.coli, Salmonella typhi, Staphylococcus aureus, Pseudomonas aeruginosa and Vibrio cholera. A routine treatment of the effluent before discharge is therefore highly recommended to maintain safe levels of the microbial pollutants.

Key Words: Actinomycetes, water pollution, fungal colonies, waste waters and Vijayawada.
\end{abstract}

\section{Introduction:}

Water is one of the prime elements responsible for life on earth as two thirds of earth's surface is covered by water. Ninety seven percent of the world's water is found in Oceans. Only $2.5 \%$ of the world's water is non-saline fresh water [1]. However, $75 \%$ of all the fresh water is bound up in glaciers and ice caps. Of the remaining $25 \%$ fresh water is found in lakes, rivers and $24 \%$ is present as ground water. Water is the essential resource for living system, industrial process, agricultural production and domestic use. The use of water increases with growing population, putting increasing strain on these water resources. An adequate supply of safe drinking water is one of the major pre requisites for a healthy life. Pollution occurs when a product added to our natural environment adversely affects nature's ability to dispose it off. A pollutant is something which adversely interferes with health, comfort, property or environment of the people. Generally, most pollutants are introduced in the environment as sewage, agricultural waste, domestic waste, industrial waste, accidental discharge and as compounds used to protect plants and animals. As a result of the increasing demand for water and shortage of supply, it is necessary to increase the rate of water development in the world and to ensure that the water is used more efficiently.

Drinking water should be suitable for human consumption and for all usual domestic purposes. The importance of water in daily living makes it imperative that through examinations be conducted on it before consumption [2]. The determination of drinking water quality guideline value is essential in order to avoid health risks to the consumers. In developing countries only a small proportion of the waste water produced by severed communities is treated. Developing country governments and their regulatory agencies, as well as local authorities (which maybe city or town councils or specific waste water treatment authorities or more generally waste and sewage authorities) need to understand that domestic and other waste waters require treatment before discharge or preferably recycle and reuse in agriculture or aquaculture[3]. The qualities of water need to be evaluated thoroughly to generate base line information for welfare of society. It is necessary to isolate and identify the microorganisms present in the different water samples. In order to alleviate microbial water pollution first a systematic study on the types and concentration of microbes present in different sources at different seasons is to be made. With this objective in view, the present work is planned to assess the quality of water in and around Vijayawada city from seven different sites (Fig.1) for microbiological parameters and the results are compared with the standards given by WHO, determined the extent of microbial pollution and recommendations suggested to improve the quality of Krishna river water. 


\section{Materials And Methods:}

SAMPLE LOCATION \& COLLECTION

Vijayawada, popularly known as fertilizer city and city of victory is situated in between $15^{\circ}-43^{\prime}$ and 17-10' North Latitude and $80^{\circ}$ and 81-33' East Longitude in Andhra Pradesh with a population of over $86,210,007$. The city has an area of about $5.8 \mathrm{sq} \mathrm{km}$ and has a flat altitude with an average ground level of $125 \mathrm{~m}$ above sea level. The communities around the river use the water extensively for drinking, irrigation, industrial and other domestic purposes without prior treatment. The microbiological parameters determined according to procedures outlined in the Standard Methods for the Examinations of Water and Wastewater [4]. Surface waters were collected from all the canals, drains and river on a monthly basis and segmented as per three season'smonsoon, pre-monsoon and post monsoon for the year 2012. The samples collected and stored in clean polythene bottles fitted with screw caps and brought to the laboratory in the sampling for detailed microbiological analysis.

\section{SAMPLE PRESERVATION}

To minimize the potential for volatilization or biodegradation between sampling and analysis, the samples are kept in refrigerator and stored at $4^{0} \mathrm{C}$.

\section{MICROBIAL EXAMINATION OF WATER SAMPLE:}

For the isolation of microorganisms such as fungi, bacteria and actinomycetes heterotrophic plate technique has been employed. Inoculation were made and incubated at $37^{\circ} \mathrm{C}$ for $24-48$ hours. The colonies developed on agar plate were counted. For the identification of different organisms present in seven water samples collected. Different media such as M. Endo agar, Pseudomonas Hi.Veg agar and Thiosulphate Citrate Bile salt sucrose agar (TCBS) were used for sub culturing.

Detection of Salmonella species were done by the enrichment of water samples on Selinite F broth, followed by isolation of the typical organism on selective medium. Detection of Vibrio cholerae was done by enriching the samples in $1 \%$ alkaline peptone water for 6 to 8 hours followed by isolation on Thiosulphate citrate bile salt sucrose (TCBS) agar medium [5]. Enteric bacteria isolated on respective selective or differential media were identified on the basis of their colonial, morphological and biochemical properties followed by Bergey's Manual of Determination Bacteriology, 1994.

\section{Results \& Discussion:}

In the present study, a comparative analysis of microbiological characteristics of Krishna river water along with less polluted and more polluted water systems of seven sites selected were made during JanuaryDecember 2012 and based on microbiological parameters the water quality has been assessed.

\section{CHARACTERISATION OF BACTERIAL, FUNGAL AND ACTINOMYCETES ISOLATES:}

The results of heterotrophic plate count of primary culture are depicted in (Table-1). The various water and waste water samples showed different morphological characteristics when cultured on nutrient agar plates and reacted differently to the diagnostic biochemical tests. However, the isolates from the Krishna river water sample were gram positive and gram negative, catalase positive and oxidation fermentation positive, oxidase negative and have the ability to ferment sugar (Table-2). The isolates showed different behavioral pattern to indole test, motility test, voges-poskauer test, hydrogen sulphide production test and ability to utilize citrate.

\section{BACTERIOLOGICAL ANALYSIS:}

It was clear that the bacterial colonies vary according to the seasons as well as to the locations. The results of the numerical estimates of bacteria from the primary culture revealed that the waste water samples contain heavy microbial load. The highest number of bacterial colonies recorded with the value of $229 \times 10^{4} \mathrm{cfu} / \mathrm{ml}$ in site- $\mathrm{V}$, this could be attributed to rapid proliferation of microorganisms which aid in the degradation of organic matter present in the industrial effluents. The lowest number of bacterial colonies recorded with the value of $5 \times 10^{4} \mathrm{cfu} / \mathrm{ml}$ in site-I. Most propable number (MPN) method is used to indicate the faecal contamination in terms of number of coliform bacteria in all the seven sites and results obtained $(2,400 \mathrm{cfu} / \mathrm{ml})$ showed that the site-I to VII water sources were highly contaminated. Krishna river water is the main source of drinking water supply for Vijayawada city, the morphological and biochemical characterization of the isolates identified the following organisms: Staphyloccus aureus, Escherichia coli, Vibrio cholerae, Salmonella typhi and Pseudomonas aeruginosa (Table-3). The presence of these organisms in water can change the quality of water. Their presence could be attributed to the ubiquitous nature of microorganisms and the contaminated state of the river by industrial effluent which increases the organic content of the river there by 
providing excellent nutritional source for the propagation of microorganisms. The presence of faecal coliform bacterial is an indicator that a potential health hazard exists for individuals exposed to the source of water.

\section{FUNGAL ANALYSIS:}

The study revealed that all the seven water samples analysed contained fungi in relative proportions. Heavy fungal load was obtained in site- $\mathrm{V}$ with the value of $12 \times 10^{5} \mathrm{cfu} / \mathrm{ml}$. The fungi isolates include Pencillium, Fusarium, Rhizopus, Mucor and Aspergillus. Health problems associated with these organisms can cause taste and odor problems thereby affecting the aesthetic properties of water.

\section{ACTINOMYCETE ANALYSIS:}

The population density of actinomycetes varied with different water samples along with the culture media used for isolation. The highest actinomycetes population density is recorded in Krishna river water $600 \times 10^{3} \mathrm{cfu} / \mathrm{ml}$, this may be because of presence of runoff water. Actinomycetes in waters collected from water present in agricultural fields $400 \times 10^{3} \mathrm{cfu} / \mathrm{ml}$ and canal near agricultural fields $130 \times 10^{3} \mathrm{cfu} / \mathrm{ml}$ can be attributed to the availability of high amount of organic matter. Less amount of actinomycete population in seven waters from VTPS and sewage water this is perhaps due to the incompatibility between surrounding factors.

\section{Conclusion:}

The results of the microbiological analysis of water samples collected in and around Vijayawada investigated have shown that effluents from industries and agricultural waste is a major source of environmental pollution through the discharge of the effluent into the water body. The water quality is directly related to health and is important for determination of water utility. Assessment of water quality is a critical factor for assessment of pollution levels. The results from the present study clearly pointed out that waters from sites-II, IV, V, VI and VII are highly polluted as they contain high levels of dissolved solids, microbiological values are not within the permissible limits given by WHO. The waters from agricultural field's site-III and IV are contaminated with pesticide residues and agricultural waste, whereas at sites V, VI and VII from industrial effluents, diesel from rail engines and domestic wastes respectively. Elevated levels of these pollution indicators, when compared to the control would invariably affect the taste, smell, appearance and aesthetic properties of the water or could pose a potential health hazard of varying degrees to various life forms, which depend on the water for domestic and recreational purposes. Hence these waters need conventional treatment including disinfection.

\section{Recommendations:}

- The industrial effluents from SIRIS Company and VTPS are to be effectively treated before disposal to the outside as they are posing serious risk for the health of the people.

- It should be immediately ensured that not a drop of any kind of waste water is allowed to enter the Krishna River water without treatment.

- Treatment of human wastes and domestic wastes, run off from agricultural wastes should be initiated.

- Public should be made aware of the dangers of pollution. NGO'S academicians and local communities should be involved in extension programmes.

[1]. Itodo A.U and Itodo H.U (2010). Nature of Science 8(4):pg54-59.

[2]. Adermorotic C.M.A (1992). Standard methods for water and effluent analysis2:pg41-42

[3]. Duncan M (2003). Domestic water treatment in developing countries Duncan Mara. Cromwell Press, U.K.

[4]. APHA (1998). Standard Methods for the Examination of Water and waste water, $20^{\text {th }}$ edition, Washington, D.C.

[5]. Pelzar M.J., Reid R.D., Chem E.C.S. and Kreig N.R. (1996). Microbiology 5th edition, Mc Graw Hill Publication, New Delhi.

[6]. WHO (2004). World Health Organisation Guidelines for drinking water quality. Geneva.

[7]. Colle J.G., Frasher A.G., Marmion B.P., and SimmonsA(1996). Practical Mediocal Microbiology. 14 ${ }^{\text {th }}$ edition, Churchill Living Stone.

[8]. Madigon, Marinko, Parker (1997). Brock Biology of Microorganisms. International $18^{\text {th }}$ edition.

[9]. WHO (1996). Guidelines for Drinking Water Quality $2^{\text {nd }}$ edition, Volumeli, Health criteria and other supporting information. World Health Organisation. Geneva.

[10]. Holt G.J., Krieg R.N., Sneath A.H.P., Staley T.J. and Williams T.S. (1994). Bergey's Manual of Determinative Bacteriology. $9^{\text {th }}$ International edition.

\section{Acknowledgements:}

I am thankful to Dr.Smt.V.Koteswaramma, Secretary and Correspondent of Montessori Mahila Kalasala, Vijayawada, who provided lab facilities for completion of the research work. 


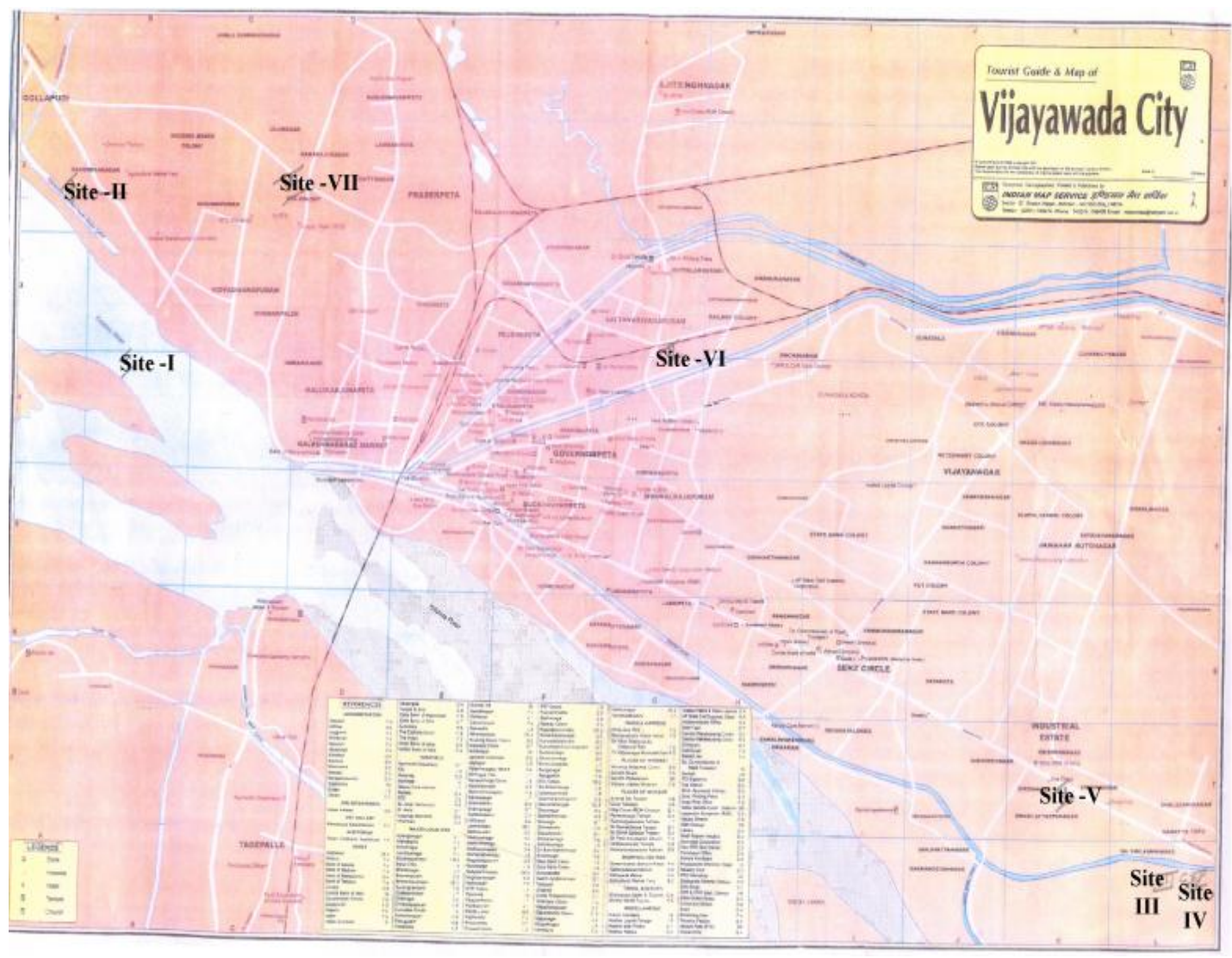

Fig.1 : Sites of Water Samples collected ( Marked in Bold Letters)

Table 1: Average values of Heterotrophic plate count of microbiological parameters from the seven sites in different months

\begin{tabular}{|c|c|c|c|c|}
\hline Heterotrophic plate count & Sites & Minimum & Sites & Maximum \\
\hline Actinomycetes $\left(1 \times 10^{3}\right)$ & V,VI,VII & $0 \times 10^{3} \mathrm{cfu} / \mathrm{ml}$ & IV & $400 \times 10^{3} \mathrm{cfu} / \mathrm{ml}$ \\
\hline Bacterial $\left(1 \times 10^{4}\right)$ & I & $5 \times 10^{4} \mathrm{cfu} / \mathrm{ml}$ & $\mathbf{V}$ & $229 \times 10^{4} \mathrm{cfu} / \mathrm{ml}$ \\
\hline Fungal $\left(1 \times 10^{5}\right)$ & II & $4 \times 10^{5} \mathrm{cfu} / \mathrm{ml}$ & $\mathbf{V}$ & $12 \times 10^{5} \mathrm{cfu} / \mathrm{ml}$ \\
\hline
\end{tabular}

Table 2: Morphological and microscopic identification of Bacteria in Krishna River Water

\begin{tabular}{|c|c|c|c|c|c|c|}
\hline S.No. & Organisms & Gram's staining & Motility & Capsule & Pigment & $\begin{array}{c}\text { Growth on } \\
\text { nutrient } \\
\text { medium } \\
\end{array}$ \\
\hline 1 & E.coli & -ve & . & -ve & +ve & +ve \\
\hline 2 & Salmonella typhi & -ve & $+v e$ & -ve & $+v e$ & $+v e$ \\
\hline 3 & $\begin{array}{c}\text { Staphylococcus } \\
\text { aureus }\end{array}$ & $+v e$ & -ve & -ve & $+v e$ & $+v e$ \\
\hline 4 & $\begin{array}{c}\text { Pseud omonas } \\
\text { aeruginosa }\end{array}$ & -ve & + ve & . & $+v e$ & + ve \\
\hline 5 & Vibrio cholera & -ve & + ve & . & $+v e$ & +ve \\
\hline
\end{tabular}

Table3: Specific Biochemical Characteristics of the identified Bacteria in Krishna River Water

\begin{tabular}{|c|c|c|c|c|c|c|c|c|c|c|}
\hline S.No. & Organisms & Oxidase & Catalase & Indole & MR & VP & Citrate & Urease & H2S & Gelatinase \\
\hline 1 & E.coli & +ve & $+v e$ & -ve & $+v e$ & -ve & +ve & -ve & -ve & -ve \\
\hline 2 & $\begin{array}{c}\text { Salmonella } \\
\text { typhi }\end{array}$ & $+v e$ & $+v e$ & -ve & $+\mathrm{ve}$ & -ve & +ve & -ve & $+\mathrm{ve}$ & +ve \\
\hline 3 & $\begin{array}{c}\text { Staphylococcus } \\
\text { aureus }\end{array}$ & $+v e$ & $+v e$ & -ve & -ve & -ve & +ve & -ve & $+\mathrm{ve}$ & $+\mathrm{ve}$ \\
\hline 4 & $\begin{array}{c}\text { Pseud omonas } \\
\text { aeruginosa }\end{array}$ & $+v e$ & +ve & -ve & -ve & -ve & +ve & -ve & $+\mathrm{ve}$ & +ve \\
\hline 5 & Vibrio cholera & +ve & +ve & +ve & -ve & + te & +ve & -ve & . & $+v e$ \\
\hline
\end{tabular}

+ (Positive)

- (Negative)

- (Insignificant) 
Fig.2 Diversity of bacteria in the water samples collected from Krishna River

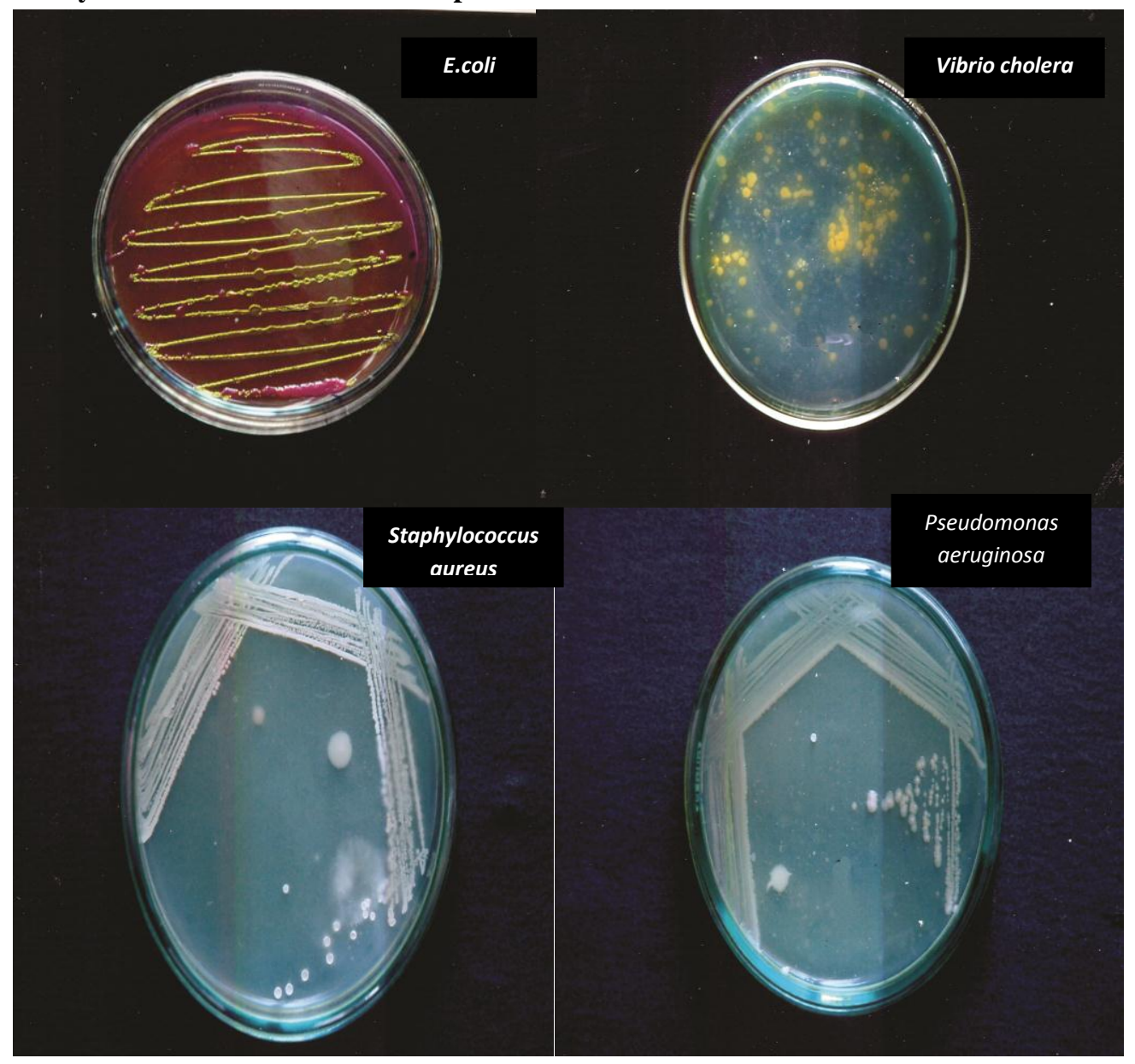

